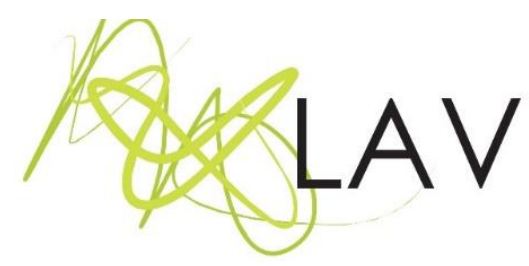

\title{
Autobiografia \\ Caminhos percorridos que me transformaram em uma Professora de Artes Visuais
}

\author{
Autobiography \\ Paths that have made me a Professor of Visual Arts
}

Ana Luiza de Freitas Duarte ${ }^{i}$

Professora de Arte da Secretaria Municipal de Educação de Goiânia

\begin{abstract}
Resumo
Esse relato tem como objetivo mostrar os caminhos percorridos por mim para tentar compreender como me tornei uma professora de Arte. Embora eu tenha me tornado uma professora de Artes Visuais e licenciada especificamente em Desenho e Plástica (modelagem), em minhas vivências pessoais não me faltaram as demais linguagens artísticas, ainda que de forma tímida ou apenas esboçada, como vocês verão em meu relato. Como pessoa, senti necessidade de experimentar diferentes formas de expressão, pois me despertavam para diferentes sentimentos que gostava, mas como profissional fiquei naquela linguagem onde senti que era a minha maior facilidade de expressão: as artes visuais. Meus tópicos são divididos em tempos vividos, e o tempo eu o dividi em função das Instituições por onde eu passei, porque cada uma delas deixou algo bem marcado e bem vivo em minha memória. Por isso a divisão é desigual e, aparentemente, sem critério, porém, foram os caminhos que a vida me proporcionou.
\end{abstract}

Palavras-chave: autobiografia, Licenciatura em Desenho e Plástica, Artes-visuais.

\begin{abstract}
This report aims to show the paths I have taken to try to understand how I became an art teacher. Although I have become a Visual Arts teacher specifically licensed in Drawing and Plastic (modeling), in my personal experiences, other artistic languages have not been missed, albeit in a timid or just outlined way, as you will see in my report. As a person, I felt the need to try out different forms of expression because I was awakened to different feelings that I liked, but as a professional I stayed in that language where I felt it was my greatest ease of expression: the visual arts. My topics are divided into times lived, which I have divided according to the Institutions where I went, because each one left something well marked and very alive in my memory. So the division is unequal and, seemingly, without criterion, but, those were the ways that life has given me.
\end{abstract}

Keywords: autobiography, licentiate degree in drawing and plastic, visual arts. 
Esse relato tem por fim mostrar os caminhos, por mim percorridos, para tentar compreender como me tornei uma professora de Arte.

Embora eu tenha me tornado uma professora de Artes Visuais e licenciado especificamente em Desenho e Plástica (modelagem), em minhas vivências pessoais não me faltaram as demais linguagens artísticas, ainda que de forma tímida ou apenas esboçada, como vocês verão em meu relato.

Como pessoa, senti necessidade de experimentar de tudo porque gostava, e ainda gosto de todas as formas de expressão, mas como profissional, fiquei naquela linguagem onde sinto que está a minha maior facilidade de expressão: as artes visuais.

Nasci em Jataí - Goiás, aos 9 de fevereiro de 1954 às 9h., filha do casal Elizeu Almeida Cunha e Adelina Maria de Freitas. Ainda antes de completar um ano, mudamos para Paranaíba-MT, onde tive minhas primeiras experiências com viagens em trem-de-ferro, Maria Fumaça, carros, ônibus, onde conheci as emas, seriemas e avestruzes.

Aos dois anos, papai fez uma cadeirinha para eu balançar debaixo da mangueira e eu o acompanhei o tempo todo. Depois fez outra cadeirinha para eu me sentar e pintou de cor vermelho grená. Eu também acompanhei todos seus movimentos. Assim eu já cresci sabendo que precisava solvente para lavar os pincéis e não estragá-los; usar o grampo de carpinteiro para a cola cascola e araldite secar; fazer encaixe usando o esquadro; transferir medidas usando o compasso... Toda essa vivência deu-me o suporte para mais tarde montar minha própria oficina.

Minha mãe engravidou, pela segunda vez, e resolveram mudar de volta para Jataí para que a mamãe pudesse estar acompanhada pela vovó e suas irmãs: Tia Almerinda, Tia Maria e Tia Nita. Nesta fase de minha vida, a linguagem artística mais viva era a música de sanfona porque meu pai tocava, dançava comigo e me fazia dormir assim, embalada pela música.

Vários tios meus tocavam sanfona e um primo tocava harpa Paraguaia. Eles adoravam declamar poesias e fazer festas e mutirões nas fazendas para ajudar quem estivesse colhendo café, milho, feijão e fumo. Eu cresci nesse meio onde o trabalho era feito com alegria, e para mim, a vida parecia ser uma festa! Havia sempre muita comida e muito doce onde havia reunião de muitas pessoas.

Sem dúvida, aqui tive a minha iniciação ao universo do som, dos ritmos, das harmonias, das melodias, criando as bases para as distinções auditivas da linguagem: uma 
prefiguração da alfabetização. Aqui tive também minha integração com as plantas e os animais e com o mundo agrícola e do mercado de trabalho porque convivia com as lavouras e os peões das roças arrendadas pelos meus avós.

Aos seis anos ingressei na escola. Fui alfabetizada na residência da madrinha Elza pegando aula particular. Ela adotou a cartilha do Povo. Para ter certeza que eu realmente sabia ler, ela furava o papel de pão no tamanho de uma palavra e encobria as figuras deixando só a palavra e me pedia para ler salteando e nunca na sequência da cartilha. A preocupação de minha professora era exclusivamente com a leitura e a escrita.

No recreio balançávamos numa gangorra debaixo de uma paineira que havia no fundo do quintal. Mas não havia nenhum momento de criação artística. Nem desenho, nem artes manuais, artesanato, nem música. Era leitura e escrita o tempo todo. Com isso, o desenho para mim era uma atividade de laser. Era algo livre, exercitado em casa porque não havia desenho na escola. O desenho que havia lá era o de caligrafia.

Já em casa, minha mãe me estimulava a ler a literatura infantil comprando todos os livros de história que surgia nas Bancas de Revista. Lembro-me de que eu sempre gostei de ler mais as gravuras e os desenhos do que o texto. Nessa idade, eu convivia com as tias Maria Gomes e Clarenita que já cursavam o ginásio e faziam uns desenhos de faixas decorativas contornadas com nanquim e coloridas com lápis de cor.

Eu ficava toda entusiasmada apreciando seus trabalhos, seus cadernos que eram extremamente limpos! Nenhuma sujeira, nenhum rabisco fora do lugar, nenhuma orelha de burro. A princípio eu usava a caixa de lápis de cor da tia Nita e, posteriormente, mamãe comprou uma caixa de lápis de cor e um caderno de desenho para mim. A partir daí, sempre que um caderno de desenho acabava, ela comprava outro.

Nesse tempo eu tinha muito verme e lombriga solitária. Como nenhum remédio estava resolvendo, meus pais decidiram me levar para passar uma temporada nos Pilões, onde existia uma água azôta, horrível, mas eu tinha que tomá-la muitas vezes ao dia e tomar o banho naquela água também. Ficamos acampados numa beira-rio ao pé de um morro e nossa brincadeira predileta, além de escalar o morro para ver a estrada lá do alto e pular cordas naquele areião, era modelar panelinhas e utensílios domésticos com argila branca e preta que eram naturais de lá. Fiquei assim numa imersão de um mês e ainda levei argila para casa para, posteriormente, modelar. Aqui desenvolvi muito minha coordenação motora grossa e fina e o amadurecimento de meu esquema corporal e sobretudo, o prazer do movimento, indispensável ao crescimento total.

Revista Digital do LAV - Santa Maria - vol. 11, n. 2, p.62 - 83 - mai./ago. 2018 ISSN 1983 - 7348 http://dx.doi.org/10.5902/1983734833897 
Ainda nessa idade, minha avó me levou várias vezes ao cerrado com o objetivo de catar folhas de lixa para lixar os móveis e mantê-los limpos e bem-acabados, sem nenhuma farpa. Aqui eu tive minha iniciação nas oficinas de marcenaria, além de ficar horas e horas olhando meu tio Cronwel, carpinteiro, cortar e encaixar as madeiras das traves das casas.

Portanto, nessa fase tive minha iniciação ao Desenho, a Modelagem e uma preparação para o Artesanato.

Em 1962, eu já estava bem alfabetizada, então me transferiram para o Colégio Estadual Deputado Serafim de Carvalho. Esta escola ficava bem distante de minha casa e não tínhamos meio de transporte. Era preciso fazer uma boa caminhada até chegar lá. De lá, o que eu mais gostava era de cantar o Hino Nacional e o Hino da Independência antes de entrar na sala de aula. Isso era feito todos os dias. Formávamos filas por turma e cantávamos enfileirados do menor para o maior. Em seguida, entrávamos para a sala de aula.

A professora Laura dava muita ênfase aos jogos e eu detestava jogos e esportes. Tinha pavor dos jogos de queimada e barra manteiga. Não sentia prazer nem mesmo de ver os colegas jogarem. Para mim, era uma estupidez jogar a bola para queimar os colegas e ficava só correndo e me defendendo da bola o tempo todo. Por fim, comecei a me esconder para não participar dos jogos. De tudo que a Professora Laura me ensinou, que ficou para a posteridade, foi a bordar o ponto corrente. Bordei um pêssego num forrinho para cobrir bandeja que penso ainda tê-lo guardado comigo de lembrança, como um modelo. Dessa experiência, o que mais valeu foram os colegas que eu adorava.

Entretanto, em casa, me aprazia usar a tesoura, recortar retalhos e costurar roupinhas para as bonecas. Eu criava um barrado xadrez e passava costuras retas com linhas de diferentes cores e fazia as saias dos vestidos das bonecas, bordadas à máquina! Eu costurava os caderninhos de bonecas dobrando uma página do meu caderno em várias páginas, usando a máquina de costura da mamãe.

Minha brincadeira predileta era brincar de escolinha. Tanto eu dava aula para as bonecas quanto para meus vizinhos mais novos. O incrível que observo hoje é que eu não dava aula de desenho para eles. O desenho era lazer. Eu dava matéria: Português e Matemática. Eu repetia o que faziam comigo. Entretanto, quando tinha meus treze anos, tinha absoluta certeza de que gostaria de ser professora de Arte.

Revista Digital do LAV - Santa Maria - vol. 11, n. 2, p.62 - 83 - mai./ago. 2018 ISSN 1983 - 7348 http://dx.doi.org/10.5902/1983734833897 
Gostava também de recortar figuras e de fazer colagens. Minha mãe comprava todas as figurinhas e álbuns de figurinhas que apareciam nas bancas de revista para estimular minha leitura. Eu gostava muito, mas nem sempre me interessava pela leitura. Para mim, o mais interessante era o desenho. Até hoje prefiro os livros ilustrados e as aulas ilustradas e gosto de ilustrar tudo que faço. A partir dessa idade já me tornei uma grande colecionadora de figurinhas.

Nessa fase tive outras grandes iniciações: ao Corte e Costura, ao bordado, as Colagens, ao Civismo e ao Magistério. Aqui eu noto minha primeira resistência: ao esporte e jogos de bola.

Aos nove anos fui transferida para o Grupo Escolar Jataí onde fiz a terceira série com a Professora Mariza Magalhães. Aqui eu fiz muito exercício de caligrafia porque minha professora tinha a letra mais bonita e delicada do mundo!

Também foi com ela que usei a caneta pela primeira vez. Ela me ensinou a usar um caderno para rascunho em sala e ao chegar à minha casa, passar tudo à limpo em outro caderno, usando a caneta. Ganhei de minha mãe uma caneta tinteiro Parque 21 e aprendi a usá-la. Já chegava em casa louca para passar as matérias à limpo! Esse hábito eu tenho até hoje. Se tiver um curso de final de semana, com certeza, levarei um mês inteiro para passar a limpo porque é nesse momento que irei pesquisar, olhar dicionários, enciclopédias, ver filmes, assistir vídeos e ler os livros indicados, fazer fichas de leitura, selecionar as figuras pertinentes às matérias, desenhar algo que a matéria tenha me inspirado, escrever poemas e textos sobre o tema. Essa disciplina de estudo que tenho hoje devo, em grande parte, à Mariza Magalhães.

Na quarta série fui aluna da Irany. A letra dela era cursiva, redonda, grande, não tinha a delicadeza da letra da Marisa. Ela também não dava aula de artes. Ela dava mais ênfase à Matemática e, em especial à tabuada e aos Estudos Sociais. Mas ela permitia que eu colasse decalques para enfeitar meus cadernos. Para colar um decalque era necessário mergulhá-lo em água e deixá-lo soltar, amolecendo sua cola. Depois deslizávamos a pontinha em uma lateral e grudava sua ponta na página do caderno. Íamos deslizando o papel de suporte do decalque e com uma toalhinha, secávamos o decalque ao mesmo tempo em que tirávamos as bolhas de ar. Se não tivéssemos habilidade, o decalque poderia rasgar; criar bolha; ondular a página do caderno ou colar torto. Mas eu tinha habilidade para fazer isso de forma perfeita!

Revista Digital do LAV - Santa Maria - vol. 11, n. 2, p.62 - 83 - mai./ago. 2018 ISSN 1983 - 7348 http://dx.doi.org/10.5902/1983734833897 
Não me lembro, de um dia sequer, ter tido alguma aula de arte ou desenho. Em compensação, com ela desenvolvi outra coisa: ela colou um retrato de Cristo numa cartolina e fixou na sala, acima do quadro-giz, e escreveu com letras recortadas no papel laminado azul: Viva Jesus... (foto de Cristo com seu coração à vista) e abaixo da foto, "em nossos corações". Ao entrar em sala ela dizia: - Viva Jesus... e a turma respondia em uníssono: em nossos corações! Com ela fui aprendendo a me centrar para iniciar um dia novo. O re-ligare que o Jung fala estava sendo iniciado ali naquele instante porque era um exercício de voltar para dentro de nossos corações e tornar viva a presença de Cristo naquilo que iríamos fazer. Essa rotina era diferente daquela outra de ir ao Centro Espírita quando estivesse passando mal e precisando de um passe. Diferente também de ter, em separado, um momento para orar e outro para estudar.

No final do ano, ganhei de presente de Natal, de meu pai, um livro das Edições de ouro chamado "Como desenhar animais selvagens". Meu tempo livre a partir de então, era preenchido desenhando animais. Fui deixando aos poucos as paisagens e tomando gosto com o desenho de animais. Como o livro era em preto e branco, despertei-me para o desenho em grafite. A imitação ficava perfeita sem usar lápis de cor. Aqui, sem saber, fui iniciada na técnica de grafite que mais tarde aprimorei na faculdade.

Em casa, junto à minha família, outra brincadeira que gostava muito era de teatrinho. Montamos nosso teatro num corredor entre duas casas. Lia as estórias, ensaiava com minhas amigas e apresentávamos para os meus tios e minha mãe. Para isso, fazíamos os ingressos desenhados em folhas de laranjeira usando os espinhos para perfurar a folha e escrever o preço dos ingressos e o nome da peça de teatro. Sem querer e sem saber, aqui fiz minha iniciação ao Desenho Publicitário, matéria essa que mais tarde passei em primeiro lugar num concurso para dar aula em uma autarquia de ensino profissionalizante.

A peça que eu mais gostava era da "Bruxulina", uma mulher toda atrapalhada, sem noções de higiene e boas maneiras. Eu adorava fazer esse papel! Na vida real, eu era muito certinha, tinha a preocupação de ser boa filha e não fazer nada errado, nada que pudesse ser motivo de risos ou chacotas, mas no teatro eu amava esse papel! A partir desse momento, comecei a ter noção de que certos comportamentos fora do teatro eram inadequados, mas que ali tudo era aceitável. Essa foi minha principal válvula de escapes para liberar-me do reprimido. Eu me identificava sempre com os papéis opostos aos meus da vida real. Penso que aquelas brincadeiras me ajudaram a equilibrar, emocionalmente, e fazer importantes catarses emocionais. Nessa época eu já tinha 
frequentes dores de gargantas, inflamações e febres. E o teatro foi para mim um Santo Remédio!

Nessa fase tive outras importantes iniciações: à caligrafia, à colagem, ao teatro, ao desenho de animais; ao desenho à grafite e ao desenho publicitário. Entretanto, percebi, em mim, uma grande rejeição às músicas sertanejas, em especial às caipiras como "O Rei do Gado" e o "Rei do Café". Quando meus tios as colocavam para tocar, eu ia para o fundo do quintal para não as ouvis.

Aos onze anos, em 1965, já havia concluído o curso primário, então fui transferida para o Grupo Escolar José Feliciano, onde cursei o Admissão ao Ginásio. Nessa fase fui aluna da Professora Marieta, que dava desenho livre aos sábados. Adorava as aulas do sábado por causa do desenho livre. Adorava desenhar paisagens com lápis de cor.

Também, nessa idade, eu já me interessava pelo bordado e pela pintura. Quando chegava a uma casa estranha, e via nas paredes da sala, as pinturas de paisagem da artista Odalva, eu perdia a noção do tempo contemplando e desejando pintar telas a óleo. Odalva pintava muitas árvores floridas, rodas D'água, lagos, casinhas no meio do mato.... Nunca a conheci pessoalmente, mas o seu estilo eu conheço até hoje. Se eu visse um trabalho dela saberia imediatamente reconhecer sua autoria, mesmo sem assinatura. Anos depois, vi um trabalho dela em Goiânia e identifiquei imediatamente. Chegando próximo, vi sua assinatura e confirmei.

Nessa época eu comecei a frequentar a Campanha Auta-de-Souza, organizada pelo Centro Espírita Allan Kardec. Nosso trabalho era dividido por ruas. A cada final de semana fazíamos uma rua de ponta a ponta. Dessa forma, fiquei conhecendo todas as casas da cidade porque entrávamos na sala para conversar sobre a campanha e aguardar que as pessoas pegassem para nós os mantimentos, que depois seriam distribuídos aos pobres. Íamos sempre em duplas. Muitas vezes, enquanto meu parceiro esclarecia, eu ficava embevecida olhando os quadros da parede. Essas paredes foram as primeiras galerias de arte que conheci. O povo jataiense dava muito valor às reproduções de importantes obras de arte, mas original e popular que eu via era somente as pinturas da Odalva.

Aqui iniciei minha apreciação artística, a distinção de estilos e a identificação de uma obra original.

Aos doze anos ingressei no Ginásio. Estudava no Colégio Estadual Nestório Ribeiro. Tinha excelentes professores em todas as matérias, menos em História. A melhor professora de 
História que conheci chamava Henriqueta Lisboa, mas ela deu aula somente por três meses e mudou-se de lá. Como os demais professores de História não conseguiam me prender a atenção, fui reprovada e tive que repetir a série. Nas demais séries consegui passar em História, mas nunca aprendi. Só na Universidade passei, de fato, a achar interessante quando fiz História da Arte com Adelmo Café.

Na quinta série ginasial, tive, pela primeira vez, um caderno para cada matéria. Gostava de escrever o nome das matérias na primeira página dos cadernos com letras adornadas. Comprei tinta e pena de nanquim, compasso de tinta e comecei a fazer desenho geométrico contornado com nanquim. Para isso, era preciso ter paciência de esperar a tinta secar para não borrar o caderno de preto, era necessário molhar a pena de forma precisa para não soltar um borrão de tinta. Com pouca tinta a escrita ficava falhada e, com muita, ficava borrada. Essa técnica desenvolveu em mim certa calma e um centramento no que estava fazendo. Não dava para fazer sem atenção.

Fui aluna de um arquiteto, o Prof. Batuira, que gostava de tudo bem medido. Ele nos ensinou a desenhar as Armas Nacionais: brasões, bandeiras, selos, escudos. Se fugisse $1 \mathrm{~mm}$. da medida ideal, ele abaixava a nota. Ele adotou o livro de Desenho do José de Arruda Penteado o qual abordava o desenho de letras; o geométrico; o desenho da figura humana; o desenho de animais e de observação. Estudei-o de capa a capa e fiz todos os exercícios sugeridos. Não tirei nem um dez com ele devido ao seu rigor nas medidas, mas foi graças a ele que me iniciei nos conhecimentos de Heráldica, que mais tarde aperfeiçoei na Universidade. Foi ele quem abriu meus caminhos para desenhar logomarcas e criar selos, brasões e bandeiras, como a que criei para o Centro Educacional Hugo de Carvalho Ramos, onde fui professora de seu filho.

Em Música, eu dizia que gostaria de ser cantora e a mamãe não concordava. Ela dizia que os cantores viviam uma vida muito irregular. Fui aluna do Maestro Rodoval Soares de Miranda, um cearense. Ele nos ensinou a solfejar. Ouvia todos os alunos um a um. Eu já tinha boa noção de ritmo e harmonia, mas nunca tinha estudado a escrita musical. Ele fazia ditados melódicos. Nessa época eu ingressei na Banda Marcial cujo regente era o Antônio Carlos, filho do Maestro Rodoval. Aprendi com ele a tocar surdo e tarol. Para isso, contei com o apoio de minha mãe. Ela fez a calça do uniforme e a blusa foi encomendada de fora. Eu ficava em êxtase, tanto nos ensaios, quanto nas apresentações. Até hoje fico embargada de emoção quando ouço uma Banda Marcial tocar. Derramo lágrimas. Mexe comigo no fundo da alma. 
Quando havia desfiles na Semana da Pátria, o que eu mais gostava, além de apresentar, era acompanhar a Banda Marcial e ver os carros alegóricos. Acredito que partiu daí o desejo de trabalhar com montagens grandes. Desejo este frustrado até hoje. Ainda desejo me engajar com os artistas das festas de Parintins onde se esculpe aquelas figuras imensas em que entramos dentro delas. Nossos carros alegóricos de Jataí eram muito bonitos, mas não chegavam nem perto dessas coisas que eu imaginava. Percebo que a frustração também é importante porque ela nos faz desejar algo fora da rotina e nos leva a nos esforçar e desenvolver o que buscamos, mesmo que tenhamos que viajar ou até mudar de cidade. Nessa época, comecei a desejar mudar para o Rio de Janeiro, onde poderia estudar na Escola de Belas Artes, que não tinha em Jataí.

Em minha adolescência eu adorava escrever poesias e prosas. Enchi dois cadernos com minhas poesias e outro com minhas escritas espontâneas (redações). Outra diversão de meus tempos livres era criar cineminha colando tiras de figuras de estórias em quadrinho e usando uma caixa de sapatos com dois cortes horizontais no fundo, por onde exibia quadrinho por quadrinho e relatava a história. Nesse tempo, a cola que eu usava era o grude que eu mesma fazia cozinhando o polvilho e descaroçando-o. Minha colagem era perfeita. Não ficava uma bolha nem ponta solta porque, se ficasse malfeita, não suportaria passar o filme que as figuras pudessem rasgar ao passar pelo corte do papelão que era feito com canivete bem afiado. Aqui dei início a contação de estórias e aperfeiçoei a colagem com outra técnica diferente dos decalques.

Ganhei, da minha mãe, um livro das Edições de Ouro chamado: "Como desenhar paisagens" Eu li e reli o livro e desenhava as paisagens já com mais consciência dos planos e da perspectiva. Continuei a desenhar com grafite porque o livro apresentava as imagens em preto e branco. Nesse período voltei para o treino de caligrafia por influência de uma colega mais velha, Eliana, que tinha a letra bonita e separada. Eu treinei escrever separado até que aprendi, ou seja, mudei minha letra. Vejo aqui uma predisposição para o autodidatismo. Começo a estudar e a me aperfeiçoar no que eu quero e não no que os professores mandam.

Nessa época, o papai começou a trabalhar com fotografias de monóculos. Aprendi com ele revelar os filmes de fotografia para monóculos e slides, com sete drogas. Cada droga revelava uma cor. $O$ tanque de revelação era bem pequeno e simples para manejar. $O$ principal segredo era estar atento ao tempo. Usávamos um cronômetro que indicava os minutos que tínhamos que deixar cada droga. Com isso, tomei gosto em montar roteiros de Histórias, fotografar e montar slides para as aulas de evangelização.

Revista Digital do LAV - Santa Maria - vol. 11, n. 2, p.62 - 83 - mai./ago. 2018 ISSN 1983 - 7348 http://dx.doi.org/10.5902/1983734833897 
Comecei também a pintar painéis de $2 \mathrm{~m} \times 3 \mathrm{~m}$ com tinta Acrilex para tecidos, com desenhos de criação minha, retratando portas de escola, para que meu pai pudesse fazer fotos de "Recordação Escolar" diante de qualquer parede feia. Pintei vários painéis de recordação escolar para o papai tirar fotos de monóculos nas escolas. Pintei também uma paisagem montanhosa com pinheiros para outras fotos que não fossem de recordação escolar. O painel foi pintado num lençol de casal.

Aqui aprendi a usar a tinta para tecidos. Muito fácil porque é à base de água e não precisa de solvente. O maior segredo é a dosagem de tinta no pincel e a quantidade de água na tinta porque ela poderá ir penetrando nas fibras e caminhando para os lados criando borrões quando o pincel estiver molhado. Para isso existe um delimitador de borrões que é transparente. Se houver uma camada de tinta branca por baixo da pintura as cores ficam mais bonitas, não borram o tecido e ficará mais econômico, gastando menos as tintas coloridas. Mas para isso é necessário dar um tempo para secar a camada de baixo para depois de seca, sobrepô-la. Isso eu fui aprendendo sozinha, sem orientação de ninguém. Aguardava ansiosa o dia de entrar na Faculdade para aprender todas essas coisas da forma "certa" como eu acreditava.

Só depois que cheguei na Faculdade foi que descobri que não existe uma forma "certa" para fazer arte e que se o professor fosse adotar um único método como sendo "o certo" ele influenciaria o aluno para o seu estilo pessoal ou para que todos tivessem um mesmo estilo - o que seria muito prejudicial. Portanto, descobri que o melhor caminho é esse mesmo em que buscamos nossa forma pessoal de auto-expressão pela exploração dos materiais.

Desde minha infância, até à adolescência, meu dentista predileto era o meu primo João Messias, conhecido por Santo. Ele tocava harpa e um dia sua harpa estragou e ele decidiu consertá-la. Para isso, precisou desmontá-la. Com isso, acabou montando uma oficina de fabricação de harpas. Os mosaicos que ele fazia com madeirinhas minúsculas para adornar suas harpas eram fantásticos! O envernizamento era perfeito! Meu primo era tão inteligente que ele próprio criou um aparelho para fazer as cordas da harpa.

Sempre que ia tratar dos dentes, pedia a ele que tocasse harpa para eu ouvir e sempre o via trabalhando na oficina de harpa ou no seu laboratório protético. Ele era um escultor de primeiríssima! As dentaduras mais bonitas e anatômicas que já conheci foram as esculpidas por ele. Além disso, ele fazia o Raio X e me mostrava, me ensinava fazer uma leitura da radiografia dentária. Foi isso que me deu as bases para, mais tarde, ilustrar a dissertação da Dra. Walgney Alves dos Santos sobre as deformações causadas pela 
técnica de instrumentação, da Universidade de Oregon, toda baseada em radiografias dentárias. Hoje ela é professora da Faculdade de Odontologia da Universidade de Anápolis.

Ouvindo meu primo eu desenvolvi minha sensibilidade musical e um gosto pelos instrumentos de corda. Mais tarde tentei aprender a tocar o violão com o Eurípedes Fontenelli - um excelente professor da UFG, mas, meus dedos eram muito moles e abafavam o som das cordas, não dando som que prestasse. Não criei calo nos dedos. Acabei por desistir. Depois meu primo fez uma harpa para mim, mas eu não tive tempo ainda para iniciar meu aprendizado. Espero que, em breve, eu possa dar início a essa nova etapa. O som da harpa é tirado apenas com as unhas, não é preciso apertar as cordas.

Convivendo com ele tive também uma boa noção de colagem, lixamento, polimento, envernizamento, moldagem, transposição de um material para o outro, interpretação de radiografias dentárias. Nessa etapa tive outras importantes iniciações: ao bico de pena; ao desenho geométrico; à Heráldica; às bandas marciais; à escrita criativa livre (redação e poesia); à fotografia; ao bico-de-pena; à escrita musical; à pintura em tecido; à criação de painéis; à contação de estórias; à montagem de audiovisuais; às aulas de Evangelização como facilitadora e ao autodidatismo. Mas, quem dera que o meu autodidatismo chegasse pelo menos aos pés de meu primo!

Concluído o Ginásio, aos dezessete anos, mudei para Catalão onde fui estudar em Regime de internato nos três turnos. Cursei três anos em um, no Centro de Formação de Professores Primários. Comecei a me interessar por fazer letras grandes com pincel atômico. Aprendi a escrever cartazes, colar figuras grandes para ilustrar os cartazes e os trabalhos solicitados pelos professores. Comecei a colecionar figuras grandes para dar aulas posteriormente. Minhas colagens seriam uma fonte de inspiração para a redação de meus alunos.

Aprendi várias técnicas de Artes com a professora Mirna. Além das técnicas, estudei Didática de Artes na Escola de $1^{\circ} \mathrm{Grau}$, em Catalão. Aqui já deu para sentir que o ensino de Arte é diferenciado das demais matérias por ter um foco divergente, onde não se obtém o mesmo resultado dos alunos como as respostas para os problemas Matemáticos, mas se assemelhava mais à Redação, onde se esperava tantas respostas diferentes quantos fossem os alunos. Entendi que a arte é uma linguagem. Senti paixão pelo trabalho de Arte, um entusiasmo todo particular porque meu foco não era encontrar a resposta que o professor almejava e sim encontrar minha própria resposta. Era a 
linguagem da alma! Eu buscava essa resposta em mim, na minha imaginação. Aqui eu poderia fazer as coisas do meu modo. Que delícia era explorar as cores, texturas, formas, descobrir o inédito e depois de pronto, eu mesma ficar surpresa com o que saiu que nem mesmo eu saberia como ficaria no final. A arte tem essa característica da surpresa, também para quem faz!

Fiz também um curso de flores em tecido. Aprendi tingir os tecidos com anilina, aprendi a usar os moldes para recortar as pétalas, engomar os tecidos, usar os boleadores para o tecido ser moldado, cobrir o arame com o papel crepom usando cola branca; montar as flores e, finalmente, montar os arranjos em jarras ou tocos de madeira. Aqui foi minha iniciação pela decoração de ambientes. Já gostava de enfeitar a mesa da sala de aula com uma jarra florida e gostava de quadros e cartazes nas paredes.

Outro curso que fiz dentro do Centro de Formação, em Catalão, foi o de Artesanato em couro. Nesse curso aprendi a usar o pirógrafo, os vazadores, ter o cuidado para não estragar a mesa (colocando papelões e sola de couro dura por baixo). Aqui conheci a tinta própria para couro "Amikron", aprendi fazer moldes para fabricar carteiras, cintos e bolsas. Aprendi também a recortar o couro com um estilete próprio, bem afiado, e a colocar ilhoses e rebites no couro, para enfeitá-lo. Eu já tinha uma boa noção de moda por ser filha de costureira, mas agora estendi esse conhecimento para os acessórios.

Pouco depois de ter retornado à Jataí, estudei o Corte e Costura. Minha mãe comprou a máquina de cobrir botões e rebitar os ilhoses e eu a auxiliava em casa, atendendo suas freguesas quando ela estava ocupada com as costuras. Anos depois, após ter concluído Licenciatura em Desenho, fiz um curso de Figurinismo na UFG, de 300 horas, para aprimorar meus desenhos de indumentárias. Tudo isso me deu a base para desenhar os figurinos de todas as Bandas Marciais das Escolas Municipais de Goiânia, mais tarde!

Aqui tivemos também um estágio supervisionado de observação das aulas da Escolinha de Alfabetização, ligada ao Centro de Formação, onde assistíamos as aulas e anotávamos tudo que observávamos de interessante, fazíamos relatórios e depois levávamos nossas dúvidas para as professoras das diferentes disciplinas.

Ao retornar de Catalão para Jataí, comecei a dar aula para apresentar meu relatório de estágio que consistia em dar aula durante dois anos para só depois pegar o certificado do Segundo Grau, porque o curso de Magistério era um curso profissionalizante. Durante esse tempo eu só trabalhei e fiz alguns cursos particulares, de curta duração.

Revista Digital do LAV - Santa Maria - vol. 11, n. 2, p.62 - 83 - mai./ago. 2018 ISSN 1983 - 7348 http://dx.doi.org/10.5902/1983734833897 
Do ponto de vista pedagógico, valeu-me muito um curso de Mestre Único, ainda em Catalão, em 1971. Em Jataí cursei o Método Montessoriano para Pais e Mestres no Instituto Espírito Santo, em 1972; outro de Psicologia e Técnicas de Ensino ainda em 1972; e outro de Oratória e Retórica no Centro Espírita Allan Kardec em 1973.

Paralelamente, desenvolvi minhas habilidades manuais fazendo cursos de bordado com fitas, sinhaninhas, linha varicor e ráfia. Aprendi a bordar o ponto rococó, ponto atrás, ponto sombra, nos paninhos finos de roupinhas para os bebês: pagãzinhas e mantinhas. Aprendi os pontos picuru, ponto cheio, ponto corrente e fazer aplicação com caseado nos enxovais de cozinha. Fiz um enxoval imenso para quando eu tivesse minha casa própria: panos de prato, forro de fogão, panos para cobrir o bujão de gás, forros de prateleiras, panos para cobrir liquidificador, filtro, caminhos de mesa etc.

Do ponto de vista histórico-social, participei de Jornadas da Educação e Cultura no tempo em que o Hélio Mauro era Secretário de Educação do Estado. Essas jornadas me auxiliaram a sair um pouco da minha alienação mental porque eu vivia fixada em tudo que era Arte, mas do ponto de vista histórico eu estava sempre muito ausente. Até hoje ainda tenho esse perfil, por mais que eu busque participar, admito que vivo mesmo como Alice no País das Maravilhas, mergulhada em meu próprio mundo imaginativo.

Nesse período o meu tio Ambrósio passava o dia todo esculpindo bois em madeira. Ele modelava os chifres com durepox e colava nos bois depois de pintados com tinta esmalte. Montava o carro de bois e, por fim, montava as juntas de bois: ora de quatro, ora de seis bois. Eu gostava muito de ir apreciar seu trabalho em sua oficina, que era extremamente simples!

Nessa fase tive outras importantes iniciações: à exploração de técnicas expressivas; aos relatórios; ao bordado profissional; ao artesanato em couro; à fabricação de flores e arranjos com tecidos; ao cartazismo e às roupas de mesa, cama e banho.

Aos 18 anos, 1972, aluguei um espaço na casa da minha Tia Almerinda e fundei uma escolinha de Alfabetização "Pernalonga". Comecei a dar aulas de alfabetização usando muitas gravuras que eu colava em cartolina e escrevia as palavras com pincel atômico. Aqui entra a fase da "fruição" que a Mestre Anna Mae Barbosa se refere na Metodologia Triangular, que fui conhecer só mais tarde, quando fiz licenciatura.

Comecei, em seguida, a treinar retrato com lápis de cor, olhando as mulheres bonitas das capas de revista porque eu gostaria de ser professora de desenho, e não de todas as matérias. Esse desejo não durou três meses e já foi concretizado. Fui convidada, pelas 
minhas habilidades já conhecidas, a dar aula nas quintas e sexta séries ginasiais e no Terceiro Normal (Segundo Grau, que eu nem tinha concluído ainda por não ser portadora de diploma, mas somente tinha as aulas teóricas), pelo seu Diretor Uriel, no Instituto Samuel Graham. Pensei que não era o momento para tudo isso, mas na cidade não tinha nenhum professor habilitado. Os habilitados já estavam ocupando suas funções. Eu assumi, mas isso me estimulou mais ainda a sair de Jataí o mais rápido possível! Eu sabia que estava no caminho certo, mas me sentia desqualificada!

Logo em seguida fui contratada como Regente Primário pelo Estado e comecei a dar aula de alfabetização no Grupo Escolar Frei Domingos. Ficava em um horário em uma escola e, em outro horário, na outra. Assim que recebi meus primeiros pagamentos, meu pai veio para Goiânia comprar um carro para mim. Comprou um Gordini verde água e ensinou-me a dirigir. As escolas eram longe uma da outra e não tínhamos transporte urbano. Se não fosse meu pai, eu nem pensaria em tal solução. Graças a ele, com 18 anos, eu já dirigia para todo lado com meu carro próprio.

Nessa altura, assinei novo contrato com o Governo Estadual e comecei a dar aula de arte para as quintas e sextas séries ginasiais. Para não ter que dar aulas nos três turnos, ficando sem tempo para fazer meus planos de aula, contratei a professora Agmar Martins da Silva para dar aula na Pernalonga e fiquei só com as escolas estaduais. Aqui eu treinei bastante o desenho com giz, no quadro-negro, onde eu desenhava para os alunos copiarem os desenhos. Eu priorizava os desenhos realistas com perspectiva. Eu tinha muitas turmas de adolescente, jovens e adultos. Apesar de passar o mesmo desenho para todos, eu conhecia o estilo de cada um como se fosse a letra. Quando um aluno desenhava para o outro, mesmo nem sabendo o nome dos alunos, eu sabia que aqueles desenhos tinham sido feitos pela mesma pessoa. Prendia-os com um clips, chamava-os e perguntava qual deles era o autor e dava os pontos só para o autor. Os demais, ou fariam o próprio desenho ou ficariam com zero.

Simultaneamente, comecei a dar aula para o Terceiro Normal, a disciplina de "Desenho Pedagógico", onde aprendi a estilizar os bichinhos para que os professores pudessem desenhar bem rápido quando estivessem ensinando matemática, dando noção de conjuntos. Treinei e ensinei a técnica de desenho quadriculado para que eles pudessem ampliar para uma cartolina qualquer desenho, inclusive mapas.

Aprendi a usar o mimeógrafo, a datilografar, desenhar no stêncil à álcool e à tinta e a imprimir numa máquina que prensava, semelhante à gravura. Aqui já era uma renovação. Minhas aulas já eram completamente diferentes das que eu recebi. Já tinha

Revista Digital do LAV - Santa Maria - vol. 11, n. 2, p.62 - 83 - mai./ago. 2018 ISSN 1983 - 7348 http://dx.doi.org/10.5902/1983734833897 
uma tecnologia à minha disposição. Não adotei livro. Queria ser livre para dar minhas aulas e não seguir um livro didático. Montava minhas próprias apostilas quando necessário, mas minhas aulas eram de desenho e eram essencialmente práticas. Não ensinava teoria. Eu queria ver o aluno desenhando!

Penso que aqui a minha visão foi muito unilateral e imatura. Se por um lado eu me libertara do livro didático, por outro, eu não pesquisava o interesse dos alunos. Eu ensinava o que pensava que deveria ensinar. Eu pensava que estava dando o melhor de mim e sabia o que estava fazendo, mas hoje percebo que eu não sabia. Valeu muito mais para mim do que para eles. Nem sei se valeu para eles.

Aqui foi minha iniciação como professora Regente Primária; como Professora de Magistério; ao Magistério Público de Primeiro e Segundo Graus dentro da área escolhida: Desenho e Desenho Pedagógico; Magistério Particular; Habilitação para o Trânsito; Empreendedorismo; uso de Recursos Tecnológicos na Educação e Retrato. Tudo isso foi feito de uma forma muito intuitiva, sem orientação, "nas coxas", como diz a linguagem popular. Mais tarde, depois que conheci a Prof. a Ilka Canabrava, que me conduziu a estudar Anna Mae Barbosa e Victor Lowenfield, senti-me envergonhada do que fiz, mas só restava seguir em frente procurando melhorar sempre! Hoje, penso que o melhor é simplesmente ser, e permitir que o outro também seja, em sua totalidade!

Ao concluir meus dois anos de estágio, em 1974, embora já estivesse contratada pelo governo em dois cargos, mudei para Goiânia para continuar minha formação. Agora meu foco era cursar Licenciatura em Desenho e Plástica. Tentei transferir meu contrato para Goiânia, como não consegui, abandonei o cargo até que entrei com pedido de demissão e me foi concedido. Fiz curso preparatório e prestei concurso no Instituto Araguaia e lá dei aula nas primeiras e segundas séries durante os anos de 1974 e 1975. Nessa minha experiência, com essas turmas, priorizei a redação e o desenho livre. Tudo o mais que ensinei estaria envolvido com a auto-expressão dos alunos, utilizando amplamente essas duas linguagens. Nesse tempo, eu já não gostava de desenhos mimeografados para colorir. Eu queria que o aluno fizesse o seu próprio desenho. Aqui tive também a oportunidade de fazer roteiros de Histórias e fotografar os alunos encenando e, posteriormente, montar a sequência de slides para exibir para toda escola, porque tínhamos um cinema dentro da escola.

O Professor Múcio Melo Álvares pagava muito bem, mas a turma era grande e tínhamos que corrigir os cadernos dos alunos todos os dias. No primeiro ano fiquei por conta de 
trabalhar porque o vestibular já havia passado. Aproveitei o turno Noturno para, além de corrigir os cadernos, preparar-me um pouco para enfrentar o Vestibular no final do ano.

No final de 1974, prestei o Vestibular unificado da Universidade Federal de Goiás para Licenciatura em Desenho e Plástica. Fiz primeiro o teste de aptidão e em seguida a prova do Vestibular. Passei em terceiro lugar, mesmo não tendo estudado Física, Química e nem Biologia no Segundo Grau. Além das disciplinas Pedagógicas, o que tínhamos a mais era Filosofia, Sociologia e Organização Social Política Brasileira.

Em 1975, iniciei o curso na Faculdade. Lá eu aprendi a fazer o desenho de Observação do Real e o Desenho do Modelo Vivo, com grafite e carvão. Fui aluna da Maria Veiga, exímia retratista. Fiz quatro retratos com pastel oleoso sobre papel Camurça: Jhon Dewey; Clapared; Newman e Ovide Decroly para a Galeria dos Educadores da Universidade Federal de Goiás - Faculdade de Educação. Eles estão lá expostos até hoje.

Fui aluna do Professor Antônio Henrique Peclát. Com ele aprendi a fazer Pintura a óleo, retratando a natureza morta, também por observação do real (frutas, flores, garrafas, vidros, cerâmica, couro, tecidos de seda, transparência, etc.). Minha ânsia por exercitar era muito grande. Eu queria ter tempo para exercitar mais a pintura e o desenho. Fiquei durante todo esse ano trabalhando no Instituto Araguaia e estudando.

No final do ano tomei a decisão de pedir rescisão de meu contrato para dedicar-me integralmente aos meus estudos. Gostava muito de meus alunos e de minha profissão, mas com lágrimas nos olhos, assim eu fiz. Senti que era chegado o momento de dedicarme só aos estudos.

Para cobrir minhas necessidades financeiras, fiz um financiamento na Caixa Econômica Federal chamado "Crédito Educativo" - uma bolsa que eu teria que comprometer-me a pagar quando eu já estivesse formada, com dois anos de carência. Meu pai disse que seguraria minha barra, caso eu precisasse de ajuda e eu encorajei-me a tomar tal decisão. Logo em seguida, o Governo promoveu uma Bolsa de Trabalho-Arte para a qual eu deveria fazer um projeto e, depois, apresentar meus relatórios mensais assinados por um professor Orientador. O professor Adelmo Café assinava todo mês os meus relatórios, mas me deixava inteiramente à vontade para pesquisar o que eu quisesse. Eu me sentia estimulada a pesquisar diferentes técnicas para mostrar resultados. Durante dois anos eu mantive-me sustentada por essa bolsa de trabalho.

Em seguida, quando cursei Psicologia da Educação, passei com nota dez em todos os semestres. Peguei monitoria de Psicologia na Faculdade de Educação, auxiliando a 
Professora Vera. Assim, tinha três fontes de renda na Faculdade, além de vender os trabalhos com facilidade. Eu gastava muito porque comprava materiais importados. Naquela época eram caríssimos! Além do mais, eu gostava de pagar para emoldurar meus trabalhos. Fiz das paredes da minha casa era uma verdadeira galeria!

Durante esse tempo em que fiquei por conta do curso, eu viajei para o Projeto Rondon três vezes. Estagiei por 40 dias no Projeto Rondon, dando aula de desenho, no Município de Jaguaribe-Ceará. Depois ficamos durante um mês em Picos-Piaui, onde fundamos uma escolinha de Arte nos moldes da Escola de Arte Veiga Valle. Estagiei dando Curso de Pintura em tecido no município de Altinho - Pernambuco. Aproveitei para expor minhas pinturas lá e, em seguida, no município de Cachoeirinha, também no Pernambuco.

Organizamos excursão para visitarmos a Bienal de Artes em São Paulo duas vezes, e fizemos nossos relatórios das obras de arte observadas. Em Goiânia, participava de todas as exposições possíveis, comparecia às vernissages de todo artista plástico e aos lançamentos de livro de todo escritor goiano. Conheci todos os Museus de Goiânia e, quando viajava, priorizava as visitas aos Museus e às Galerias de Arte.

Nesse período, participei de Concursos de Arte em Goiânia, Paraúna, Fazenda Nova, Anápolis, Inhumas, Rubiataba, Goiás... fui premiada em desenho, pintura, objetos e literatura. Expus trabalhos nas Galerias de Arte da cidade de Goiânia, trabalhei como desenhista de Decoração de interiores para o Senhor Matusalém das Lojas Brasil Colonial, onde expunha também os meus trabalhos e os colocava à venda.

Fiz cursos extras durante todos os Festivais de Artes. Um deles foi o de "Restauração da Pintura", o que me encorajou a pegar a restauração do altar de uma Igreja em Campinas.

Trabalhei como arte-finalista para as Gráficas de Goiânia e ainda vendia meus desenhos, pinturas e gravuras. Os próprios professores da UFG me compraram vários trabalhos. Vendi trabalhos de Gouache chapado para Maria Guilhermina e para o Ângelus André Ktenas, uma série de Esgrima trabalhada com bico-de-pena. Esse período em que trabalhei como arte-finalista para as gráficas, foi posteriormente, o que me deu a base para me tornar uma professora de Desenho Publicitário no Centro Educacional Hugo de Carvalho Ramos.

Um ano após ter mudado para Goiânia, percebi que eu não retornaria mais para Jataí. Então meus pais vieram de mudança para Goiânia e meu pai montou um laboratório de fotografia em preto e branco. Eu o ajudava a retocar as fotos que tivessem ficado 
desfocadas ou com sinais brancos criados por sujeiras no momento da revelação. Nesse tempo, eu aprendi com ele, a revelar em papel fotográfico e explorei efeitos com uso de vidro, plantas, máscaras para revelar silhuetas em papel sem foto, só com a exposição da luz sobre minhas montagens. Olhando para trás, agora vejo que nem tudo eu aprendi dentro da Faculdade. Posso dizer que a maioria do que sei, realmente, foi porque tive muitas oportunidades de aprender coisas fora da sala de aula e agregar ao que vou estudando na escola. E, ainda, continuo com esse mesmo perfil. Nunca deixei de frequentar cursos, nem de ler outros livros fora dos sugeridos, nem de experimentar algo diferente. Fica muito claro que a escola é o principal local de socialização, mas a construção do conhecimento e, principalmente do saber, é um ato solitário. Cada indivíduo precisa se dedicar ao que quer aprender e saber!

Na Faculdade fui pegando outras disciplinas e adquirindo novas habilidades. Fui montando também o meu próprio currículo porque eu me interessava por muitas matérias dos demais cursos e me matriculava como matéria eletiva. Assim, fiz quase todas as matérias do bacharelado e do Instituto de Ciências Humanas e Letras, fiz o Francês com o José Alves Zannata e Italiano com a Profa. Silvia Siqueira Simões.

Aprendi, com o Professor Ângelus André Katenas, artista grego que veio morar no Brasil, a modelar o corpo humano e a fazer busto em argila. Modelei, separadamente, todos os detalhes da figura humana em tamanho Normal: o torso, a cabeça, as mãos, os pés. Em escala superior ao normal, modelei orelhas, narizes, bocas, olhos e, em miniatura, o corpo completo. Ele levou-nos em seu atelier onde vimos todo processo de fazer um busto de bronze, ou outro material que precisasse derreter em alta temperatura e moldá-lo nas caixas de areia. Por medo do fogo, eu nunca quis trabalhar com isso, embora admirasse. De qualquer forma, serviu para compreender o procedimento técnico, caso resolvesse trabalhar com isso.

Com a Prof. a Maria Guilhermina, aprendi, não só a esculpir em madeira e pedra sabão, mas também, pintar com tinta gouache e aquarela, em papel tela e canson.

Com o Prof. Cleber, aprendi a fazer xilogravura, gravura em metal, ferro galvanizado e cobre. Aqui eu usei pela primeira vez as tintas gráficas e trabalhei com ácidos mais fortes do que as drogas fotográficas. Com ele aprendi, também, a técnica de trabalhar com tinta esmalte sintético queimado e tinta spray com uso de máscaras. Eu fiz uma série delas, mas não gostei porque a tinta é altamente tóxica e para isso precisaria ter um local apropriado, e não era o meu caso. Eu morava em um barraco simples no fundo da casa da minha irmã. Era muito apertado, não dava para trabalhar com esse tipo de tinta.

Revista Digital do LAV - Santa Maria - vol. 11, n. 2, p.62 - 83 - mai./ago. 2018 ISSN 1983 - 7348 http://dx.doi.org/10.5902/1983734833897 
Com a Marisa, aprendi a montar objetos em madeira e acrílico.... Aprendi a modelar em resina plástica. Fiz muitos chaveiros e prendedores de cabelo. Aperfeiçoei a pintura em couro; o uso do pirógrafo em madeira; o uso da serra tico-tico para cortar curvas no Duratex, o isocorte para montar letras e objetos com isopor; a colagem de materiais diversificados. Aqui fui percebendo que para cada tipo de material há uma cola mais apropriada. Fui experimentando uma diversidade de colas e me acostumando com cada uma delas. Com meu pai já havia aprendido a usar a cola de sapateiro, a araldite rápida ( 2 horas) e a demorada ( 24 horas); a cascorez (cola branca) e a durepox. Mas agora aprendi a usar o clorofórmio para colar o acrílico e a cola de isopor para colar isopor. Nesse tempo ainda não tinha cola silicone. Tinha Cola Tudo, mas era muito caro e não rendia porque o tubo era pequeno.

Com a Raulice Gomes Bahia, estudei anatomia artística e aprendi o desenho anatômico. Visitei academias onde fotografei os músculos dos rapazes e, posteriormente, os desenhei. Enchi um álbum de desenhos de ossos e músculos. Visitei a sala do Curso de Medicina onde se fazia a dessecação dos cadáveres e desenhei algumas peças. Quanto ao visual, embora seja impactante, parece muito com peças de plástico. Quase não dá para acreditar que fosse de carne humana. Mas, o cheiro do éter é inesquecível e inconfundível. Perdi totalmente o apetite. Nunca mais me esqueci daquele cheiro. É estonteante!

Depois disso, fiz outra matéria com Raulice, onde aprendi a fazer colagens e montagens. Fiz quadros onde combinei penas, gravuras, palhas de chapéu, escamas de peixes, ossinhos de frango, conchas marinhas, casca de ovos, sementes e outros materiais. Fiz pintura em tela dando a textura de limalhas de ferro para representar as paredes de uma caverna de uma série "Morloques" inspirada no livro "A máquina do Tempo". Nessa disciplina, trabalhei muito com ilustrações de histórias com uso de gravuras e papel fantasia. Isso me serviu de preparação para o que hoje faço em soulcollage.

Com o Prof. Orlando, da Faculdade de Engenharia Civil, aprendi vários tipos de perspectiva; aprendi a usar o pantógrafo e o normógrafo; a régua paralela, os esquadros, o transferidor, a curva francesa, a régua flexível e a fazer projetos arquitetônicos, decorativos, elétricos e hidráulicos em papel vegetal com nanquim. Estas aulas me serviram de base para projetar a reforma de minha casa e para projetar meu gatil.

Aqui tive também outras importantes iniciações: Desenho do Modelo Vivo; Desenho Anatômico; Desenho Científico; Desenho de Observação do Real; Pintura em Tela; 
Pintura com Gouache em papel tela; Pintura com Aquarela em Papel Canson; Modelagem do Corpo Humano; Gravura em madeira(Xilogravura); Gravura em Metal; Gravura em Cobre; Gravura em Ferro Galvanizado; Gravura em Pedra(litogravura); Escultura em madeira; Escultura em Pedra Sabão; Montagem de Objetos; Montagem de figuras e mosaico de papel; Projetos Decorativos e Arquitetônicos em papel vegetal com tinta nanquim; Visitas às Exposições de arte e aos Museus; Exposições Coletivas e Individuais de meus trabalhos e Concursos de Arte.

Após concluir o curso superior, já com 25 anos, eu pintei os muros da Escola Panterinha com desenhos animados representando cenas da Panterinha, pintei paredes da Escola Infantil Cantinho do Saber na Água Branca usando tinta PVA.

Nesse período, fiz muitas artes finais para as gráficas. Inicialmente, usava o normógrafo e depois aprendi a fazer a arte-final com letrasset. Explorei o achuriador rápido para desenhar com engrossamento de linhas. Fiz até ilustração de livros usando essa técnica. Explorei também o sombreamento hachuriado e pontilhado com nanquim, criei logomarcas, capas, ilustrações e certificados.

Dei curso de Cartazista e Letrista no SENAC. Elaborei apostilas específicas para isso. Trabalhei por um ano prestando serviço na Secretaria de Agricultura. Fiz muitos desenhos de Organogramas e fluxogramas; fiz muito desenho de observação de animais domésticos nas exposições agropecuárias e, em minhas viagens, desenhava os insetos e animais marinhos e plantas encontradas nas praias e nas fazendas.

Um ano depois, prestei o Concurso para Professora de Desenho Publicitário para o Curso Profissionalizante em Publicidade. Passei em primeiro lugar e assumi a vaga. No ano seguinte houve outro concurso: para dar aulas de arte para o Curso Profissionalizante de Secretariado. Também passei em primeiro lugar e assumi as aulas. A escola era de regime integral e lá eu ficava o dia todo junto aos alunos. Criei uma sala ambiente onde tinha pranchetas para todos; armário para guardar materiais; pia com água para lavar os pincéis; TV; Telão para os audiovisuais e murais com cortiça para expor os trabalhos dos alunos. Consegui montar a sala ideal. A sala dos meus sonhos!

Nos corredores da escola tinha, permanentemente, exposições de trabalhos e as salas eram decoradas pelas turmas com minha supervisão. Em junho fazia-se decoração junina e, em dezembro, decoração natalina.

Minha dedicação era exclusiva para o Estado, até que em agosto de 1985 prestei concurso para Professora de Arte na Secretaria Municipal de Educação, onde lotei no 
turno noturno. Na SME a realidade já era totalmente diferente. Eu dava aula nas escolas da periferia de Goiânia, nos extremos opostos. Cada noite ia para uma escola diferente.

Quando ingressei na Rede Municipal eu já fazia avaliação diagnóstica para montar o plano de aula em cima da real necessidade dos alunos e não pautadas em minha imaginação. Fazia também pesquisa de interesse com eles. Tinha mais de 500 alunos e continuei recolhendo todos os trabalhos, todos os dias, e anotando num diário particular para, só no final do mês, passar as avaliações a limpo para o diário da escola. Esses alunos não tinham dinheiro para comprar materiais e eu nunca exigi que eles comprassem nada. Se tivesse lápis faria o trabalho a lápis, se tivesse caneta, faria com caneta, não precisava de borracha, o papel poderia ser qualquer um. O importante para mim era o envolvimento e o interesse.

Depois que chegava em minha casa olhava cada trabalho e anotava em meu diário um conceito: $\mathrm{F}$ (fraco); R(Regular); B(Bom); MB(Muito Bom); O(Ótimo). Analisava quais dariam um bom casamento de ideias e prendia-os com clips. Na outra aula colocava-os para sentar juntos, e pedia ao grupo para elaborar um desenho único onde as ideias de todos pudessem aparecer. Após essa etapa, dava uma sugestão de técnica a ser aplicada, sugeria um material a ser usado e pedia para levar o material na aula seguinte.

$\mathrm{Na}$ outra aula, enquanto faziam um desenho de observação do real, eu passava de grupo em grupo dando uma demonstração de técnica para que eles fizessem o acabamento. Eles se entusiasmavam e acabavam participando. Eu já deixava claro para eles que uma arte, até chegar ao final, passa por muitas etapas de construção e reconstrução. Que não tivessem medo e nem preguiça de recomeçar. E assim eu consegui resultados até melhores e mais criativos do que com as turmas de Secretariado e Publicidade.

No final do ano fazia um concurso de cartões natalinos e aquele desenho que tivesse melhor, que fosse mais criativo, seria impresso em serigrafia para todos. Eram eles que votavam e escolhiam o trabalho melhor, e não eu! A arte final era feita em papel vegetal, dentro de sala, por eles, e na outra aula eu levava a tela já com a arte gravada e imprimíamos dentro de sala, usando a mesa do professor.

Quanto ao Estado, dois anos após ter montado minha sala ambiente, minha escola foi desautarquizada, saímos da sala de aula e fomos trabalhar na sede da Secretaria de Educação. Lá, como eu trabalhava dando curso para os professores, juntei-me a Coordenadora de Arte da Delegacia Metropolitana Luz Marina de Alcântara e a um Professor da Rede Municipal de Educação Hamilton Amorim Rezende, e fizemos uma

Revista Digital do LAV - Santa Maria - vol. 11, n. 2, p.62 - 83 - mai./ago. 2018 ISSN 1983 - 7348 http://dx.doi.org/10.5902/1983734833897 
pesquisa com todos os professores contratados pelo Estado para dar aula de Arte. Nessa pesquisa sondamos quais eram suas habilitações e verificamos quais os cursos de formação continuada deveríamos oferecê-los. Por anos seguidos organizamos os Festivais de Educação Estética que aconteciam no Município de Goiás. Finalmente, criamos um Centro de Estudo e Pesquisa para os Professores de Arte, ao qual denominamos Ciranda da Arte. Não demorou muito e conseguimos uma sede própria, e hoje, o Ciranda da Arte está se ampliando com uma filial em Alto Paraíso - o Ipê Arte.

Para mim, está sendo muito interessante rememorar tudo o que fiz, porque, apesar de ser muito autocrítica, e cobrar muito de mim mesma, esse exercício de rememoração do passado me levou a chorar de gratidão por tudo que passei, pelas pessoas que conheci, pelos professores que me ensinaram e pelos alunos que me deram a oportunidade de exercer minhas habilidades didático-pedagógicas. Agradeço de coração, por cada um deles, por ter sido exatamente quem foi e como foi, sem querer mudar nada, em nenhum deles. Cada pessoa e cada situação vivida foi, para mim, um fio perfeito com o qual, adicionado aos demais, teci essa obra de arte que é a minha vida! Minha vida é o que é hoje, graças a esse somatório de todos que passaram por ela e foram adicionando cores nessa paleta com a qual pintei minha vida!

\footnotetext{
${ }^{i}$ Mestre em Ciências e Valores Humanos pela UNIUBE - Uberaba - MG 2003; Especialista em Arteterapia na Educação Especial pela UFG - Goiânia - Go 1995 ; Especialista em Técnicas de Planejamento, Controle e Avaliação - CECAP- Go - 1985; Extensão Universitária em Educação em Direitos Humanos: Cultura da Paz e Cidadania - UFG 2002 ; Educação para a Paz na Fundação Peirópolis - MG - 1996; Metodologia em Educação em Valores Humanos - Fundação Peirópolis - MG - 1997; Psicoterapia Transdisciplinar, Arteterapia e Xamanismo - 2005 com MALUBA - Goiânia; Licenciatura em Desenho e Plástica pela UFG - Goiânia 1979. Cursando: Psicologia Analítica e Eneacouching pela UNIPAZ - Go. Professora de Arte aposentada pelo Estado de Goiás em 2004. Foi Coordenadora e Supervisora de Arteterapia no Projeto arte Educação, Fund. Jaime Câmara-2003; Professora de Arte na Secretaria Municipal de Educação desde 1985; Arte-finalista desde 1989 nas secretarias de Educação do Estado e Prefeitura de Goiânia; Arteterapeuta desde 1985 com atuação na SME, Congressos e em Consultórios; Faz parte do Sindicato Nacional dos terapeutas como terapeuta holística desde 2002; Ilustradora desde 1985.
}

Como citar esse artigo:

DUARTE, Ana Luiza de Freitas. Autobiografia Caminhos percorridos que me transformaram em uma Professora de Artes Visuais. Revista Digital do LAV, Santa Maria: UFSM, v. 11, n. 2, p. 62-83, mai./ago. 2018. 